УДК 336.143.2:352

Юрчишена Л.В., к.е.н., доцент Донецького національного університету ім. Василя Стуса

Горлов E.I., магістр Донецького національного університету імені Василя Стуса

\title{
ПІДВИЩЕННЯ ДОХОДІВ МІСЦЕВИХ БЮДЖЕТІВ НА ОСНОВІ СТИМУЛЮВАННЯ РОЗВИТКУ МАЛОГО ТА СЕРЕДНЬОГО БIЗHECУ
}

В статті розглянуті основні джерела наповнення дохідної частини місцевого бюджету, а саме податкові й неподаткові надходження та інші. Досліджено проблеми наповнення місцевих бюджетів в умовах децентралізації та визначено, яким чином місцевим органам влади необхідно впливати на розвиток бази надходжень закріплених доходів і збільшення чистки власних доходів. Проведено аналіз сучасного стану доходів місцевих бюджетів 5 міст, а саме: м. Вінниці, м. Чернігова, м. ІваноФранківська, м. Чернівці, м. Житомира та визначено обсяги фінансування програмних заходів та проектів 3 підтримки малого та середнього підприємництва в цих містах. Визначено важливість розвитку малого та середнього підприємництва на місцевому рівні. Розроблено концепцію збільшення доходів місцевого бюджету за рахунок розвитку малого та середнього підприємництва, визначено основні її задачі та методи досягнення її мети.

Ключові слова: місцевий бюджет, доходи місцевого бюджету, власні доходи, податкові надходження, розвиток малого та середнього бізнесу.

Рис. 7, Табл. 2, Літ. 8.

\section{Юрчишена Л.В., Горлов Е.И.}

\section{ПОВЫШЕНИЕ ДОХОДОВ МЕСТНЫХ БЮДЖЕТОВ НА ОСНОВЕ СТИМУЛИРОВАНИЕ РАЗВИТИЯ МАЛОГО И СРЕДНЕГО БИЗНЕСА}

В статье рассмотрены основные источники наполнения доходной части местного бюджета, а именно налоговые и неналоговые поступления, а также другие. Исследованы проблемы наполнения местных бюджетов в условиях децентрализации и определено, каким образом местным органам власти необходимо воздействовать на развитие базы поступлений закрепленных доходов и увеличение части собственных доходов. Проведен анализ современного состояния доходов местных бюджетов 5 городов, а именно: Винницы, Чернигова, Ивано-Франковска, Черновцов, Житомира и определены объемы финансирования программных документов (мероприятий, проектов) по поддержке малого и среднего предпринимательства в этих городах. Определена важность развития малого и среднего предпринимательства на местном уровне. Разработана концепция увеличения доходов местного бюджета за счет развития малого и среднего предпринимательства, определены основные ее задачи и методы достижения ее цели.

Ключевые слова: местный бюджет, доходы местного бюджета, собственные доходы, налоговые поступления, развитие малого и среднего бизнеса. 
Yurchishena L., Horlov Y.

\section{INCREASE OF INCOMES OF LOCAL BUDGETS ON THE BASIS OF STIMULATING THE DEVELOPMENT OF SMALL AND MEDIUM BUSINESSES}

The article considers the main sources of filling the revenue part of the local budget, namely tax, non-tax revenues and others. The problems of filling local budgets in the conditions of decentralization are investigated, and it is determined how the local authorities need to influence the development of the income earnings base and increase the part of their own income. Using the information of the Main Directorate of Statistics and open data provided by the relevant executive bodies of the local government, an analysis of the current state of income of local budgets of 5 cities, namely, Vinnitsa, Chernigov, Ivano-Frankivsk, Chernivtsi, Zhytomyr, and the amount of financing of program documents (activities, projects) to support small and medium-sized businesses in these cities. The importance of the development of small and medium enterprises at the local level is determined. The concept of increasing local budget revenues through the development of small and medium-sized businesses has been developed, its main objectives and methods for achieving its goal have been determined.

Key words: local budget, local budget revenues, own revenues, tax revenues, development of small and medium businesses.

Постановка проблеми. Світовий досвід господарювання свідчить, що найкраще економічний, соціальний, політичний стан розвитку на місцях усвідомлює та може реформувати місцева влада. Поряд 3 цим, саме місцева влада може (і повинна) створювати сприятливі умови для економічного зростання на місцях, задіяти всі важелі для залучення інвестицій, розвитку підприємництва, малого та середнього бізнесу, сприяти створенню нових робочих місць та зростанню самозайнятості населення. Від вирішення цих питань напряму залежить добробут місцевих мешканців, гарантії щодо поповнення місцевих бюджетів, темпи зростання надходжень до державного бюджету, а отже - й зростання добробуту країни в цілому.

Аналіз останніх досліджень i публікацій. Теоретико-методологічними проблемами формування та використання фінансових ресурсів місцевих бюджетів у вітчизняній фінансовій науці присвячені праці вчених - економістів Ю. Набатова, Н. Бак, В. Ніколенко, Л. Простебі, Д.Лук'яненко та ін. Дослідження підходів щодо підтримки й економічного розвитку малого та середнього бізнесу на регіональному рівні та як наслідок збільшення доходів місцевих бюджетів набули свого висвітлення в наукових працях вітчизняних вчених: Н. Євтушенко, Л. Чорній, О. Тимченко.

Мета статті. Метою статті $є$ аналіз сучасного стану формування місцевих бюджетів в умовах децентралізації фінансових ресурсів, визначення впливу малого та середнього підприємництва на доходи місцевих бюджетів в умовах децентралізації та визначення напрямів та методів його розвитку 3 метою збільшення податкових надходжень до міського бюджету.

Виклад основного матеріалу дослідження. До 2015 р. в Україні діяла система міжбюджетних відносин, заснована на централізованій моделі бюджетного федералізму, основні риси якої були успадковані від адміністративно-командної системи управління. 
Централізація фіскальних функцій держави обмежувала місцеві органи влади в реалізації основних функцій управління бюджетним процесом на місцях. Це проявлялося в їхній залежності від державного бюджету внаслідок збереження пріоритетності нормативного методу розподілу бюджетних коштів і високій частці трансфертів у доходах місцевих бюджетів, що негативно впливало на розвиток міжбюджетних відносин у ринковій економіці. 32015 р. в результаті змін у бюджетному та податковому законодавстві вперше за часів незалежності запроваджено децентралізацію системи міжбюджетних відносин [1].

На сьогодні поняття «місцевий бюджет» розглядається як економічна категорія та як фінансовий план місцевих органів самоврядування. Місцевий бюджет як економічна категорія - це система економічних (фінансових) відносин, які виникають між органами місцевого самоврядування, з одного боку, юридичними та фізичними особами, з іншого, між місцевими і державними органами влади й управління, а також між місцевими бюджетами різних рівнів із приводу формування та використання централізованого фонду фінансових ресурсів органів місцевого самоврядування в процесі розподілу та перерозподілу ВВП для задоволення різнобічних соціальнокультурних, комунально-побутових, інших потреб членів суспільства й регулювання соціально-економічних і фінансово-правових процесів на певній території [2].

За своєю формою місцевий бюджет - це основний фінансовий план органів місцевого самоврядування, за матеріальним змістом - централізований фонд їх фінансових ресурсів. Місцевий бюджет може складатися із загального та спеціального фондів. Загальний фонд бюджету включає:

1) всі доходи бюджету, крім тих, що призначені для зарахування до спеціального фонду;

2) всі видатки бюджету, що здійснюються за рахунок надходжень загального фонду бюджету;

3) кредитування бюджету (повернення кредитів до бюджету без визначення цільового спрямування та надання кредитів з бюджету, що здійснюється за рахунок надходжень загального фонду бюджету);

4) фінансування загального фонду бюджету [1]

Відповідно до статті 9 Бюджетного кодексу України доходи місцевих бюджетів класифікуються за такими групами:

- податкові надходження;

- неподаткові надходження;

- доходи від операцій з капіталом;

- трансферти.

Відповідно до Законів України «Про внесення змін до Бюджетного кодексу України щодо реформи міжбюджетних відносин» та «Про внесення змін до Податкового кодексу України та деяких законодавчих актів України щодо податкової реформи» [3] виділимо основні види податків і зборів, які формують дохідну частину місцевих бюджетів.

1. Податок на доходи фізичних осіб. Так, на території міст обласного значення, районів, бюджетів об'єднаних територіальних громад, роз- межування даного податку відбувається наступним чином: до Державного бюджету - 25\%; до обласних бюджетів - 15\%; до бюджетів міст обласного значення, районів, об'єднаних громад - 60\%.

2. Державне мито (100\% до місцевих бюджетів). 
3. Податок на прибуток підприємств приватного сектору економіки (10\% - до обласних бюджетів).

4. Екологічний податок (до обласних бюджетів - 30\%, до бюджетів міст обласного значення та районів $-25 \%)$.

5. Акцизний податок (ставка 5\%) 3 реалізації суб'єктами господарювання роздрібної торгівлі підакцизних товарів (пиво, алкогольні напої, тютюнові вироби, нафтопродукти). Зарахування коштів до місцевих бюджетів здійснюється за місцем розміщення об'єктів, в яких провадиться діяльність, що підлягає оподаткуванню.

6. Збори за спеціальне використання природних ресурсів.

7. Місцеві податки і збори, тощо [2].

Неподатковими надходженнями визнаються:

- доходи від власності та підприємницької діяльності;

- адміністративні збори та платежі, доходи від некомерційної господарської діяльності;

- інші неподаткові надходження.

Надходження місцевого бюджету передбачають доходи бюджету, повернення кредитів до бюджету, кошти від місцевих запозичень, повернення бюджетних коштів 3 депозитів, надходження внаслідок продажу/пред’явлення цінних паперів [1].

На сьогодні постійне прагнення до самостійності місцевих бюджетів, до подальшого розвитку та зміцнення місцевого самоврядування вимагає більшої фінансової незалежності та життєздатності органів місцевої влади. У зв'язку з цим постає питання пошуку нових інструментів та методів збільшення доходів місцевих бюджетів [4].

В Україні основними джерелами наповнення дохідної бази місцевих бюджетів $\epsilon$ закріплені доходи та офіційні трансферти, тому місцевим органам влади необхідно впливати на розвиток бази надходжень закріплених доходів і збільшення чистки власних доходів. Зокрема, необхідно забезпечувати:

- підтримку підприємств, що створюють нові робочі місця й збільшують фонд оплати праці;

- збільшення можливості впливу органів місцевого самоврядування на наповнюваність місцевих бюджетів;

- застосування режиму жорсткої економії бюджетних коштів;

- сприяння розвитку малого й середнього бізнесу;

- збільшення доходів від місцевого господарства, забезпечення прибутковості комунальних підприємств.

Дослідити доречність бюджетної децентралізації можна за допомогою аналізу формування та виконання місцевих бюджетів за доходами у 2015 році, адже саме тоді була запроваджена дана реформа. Порівнявши показники виконання дохідної частини місцевих бюджетів у 2014, 2015, 2016 та 2017 роках, дозволить виявити перші досягнення та проблеми у набутті незалежності місцевого самоврядування [5]. Результати фінансової децентралізації свідчать про щорічне зростання обсягів власних ресурсів місцевих бюджетів та зростання частки місцевих бюджетів (із трансфертами) у структурі зведеного бюджету України. Дані рис. 1, показують, що приріст доходів у 2015 році у порівнянні з 2014 роком становив 29,6 млрд. грн. (42,1 \%). 


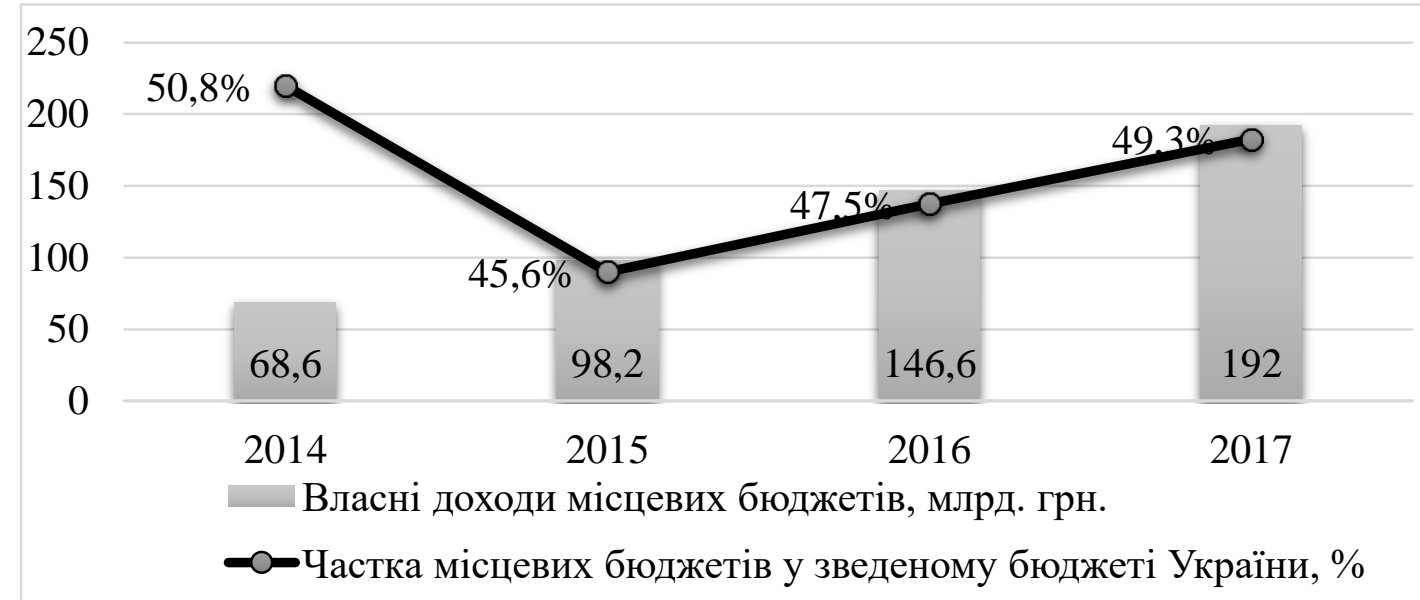

Рисунок 1 - Доходи місцевих бюджетів та їх частка у зведеному бюджеті України

Якщо доходи місцевих бюджетів у 2015 році склали 98,2 млрд. грн., то у 2016 році цей показник зріс до 146,6 млрд. грн., а приріст надходжень склав 48,4 млрд. грн. (49,3 \%).У 2017 році власні доходи місцевих бюджетів склали 192 млрд. грн., що більше на 21,3 млрд. грн. від прогнозованого показника. Частка доходів місцевих бюджетів у структурі зведеного бюджету України, починаючи з 2015 року, постійно зростала, що свідчить про можливість регіонів спрямовувати кошти на свій розвиток та реалізацію інфраструктурних проектів тощо.

Розглянемо особливості бюджетної децентралізації на прикладі бюджетів міст обласного значення, що допоможе охарактеризувати дієвість реформи в дослідженні шляхів та методів економічного розвитку території. Для аналізу були відібрані наступні міста: Вінниця, Чернігів, Івано-Франківськ, Чернівці та Житомир [6]. Критеріями для відбору були місце знаходження, загальна площа міста та кількість його населення.

Перш за все, бачимо, що починаючи 32014 року у всіх зазначених міст відзначається позитивна динаміка, так у порівнянні з 2014 роком в середньому у 2,5 рази збільшився обсяг доходів (загальний та спеціальний фонд) місцевих бюджетів (рис.2).

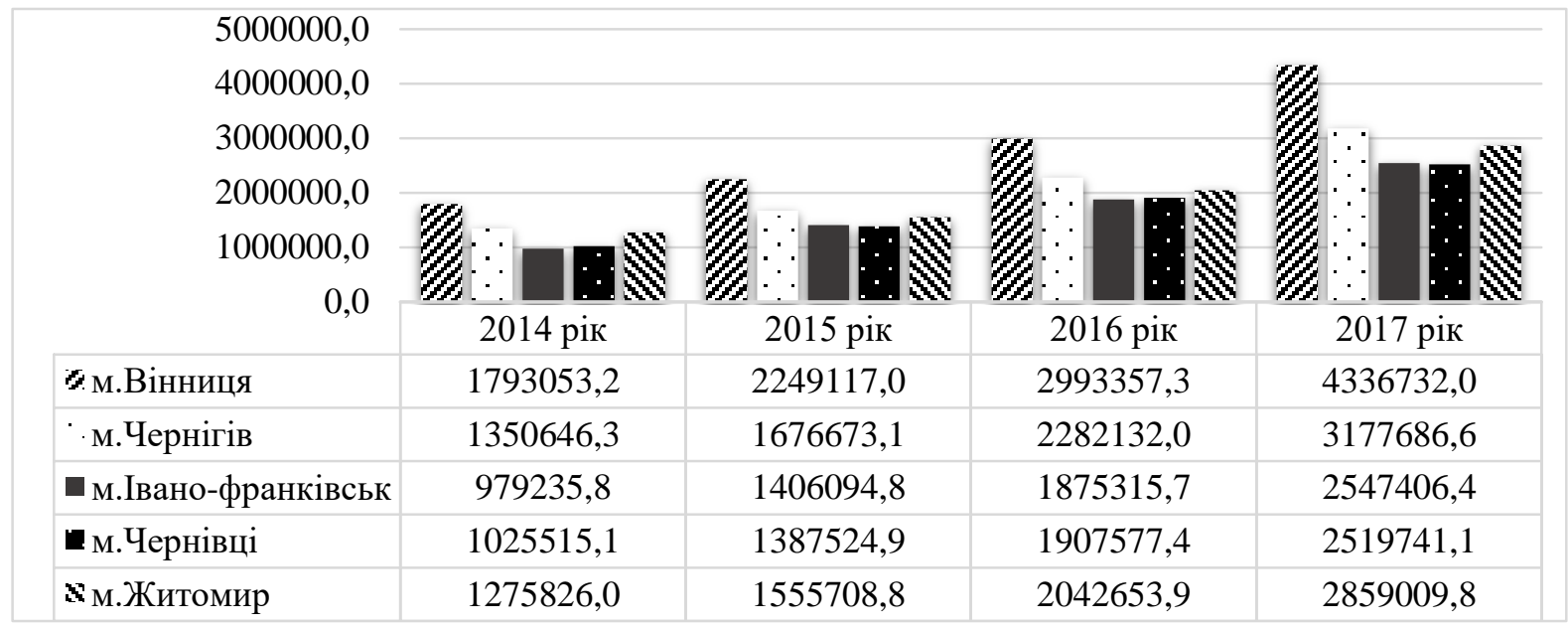

Рисунок 2 - Обсяг доходів місцевих бюджетів за 2014-2017 рік, тис. грн. 
Але для більш детальної картини розглянемо частку власних надходжень в структурі бюджету (рис. 3).

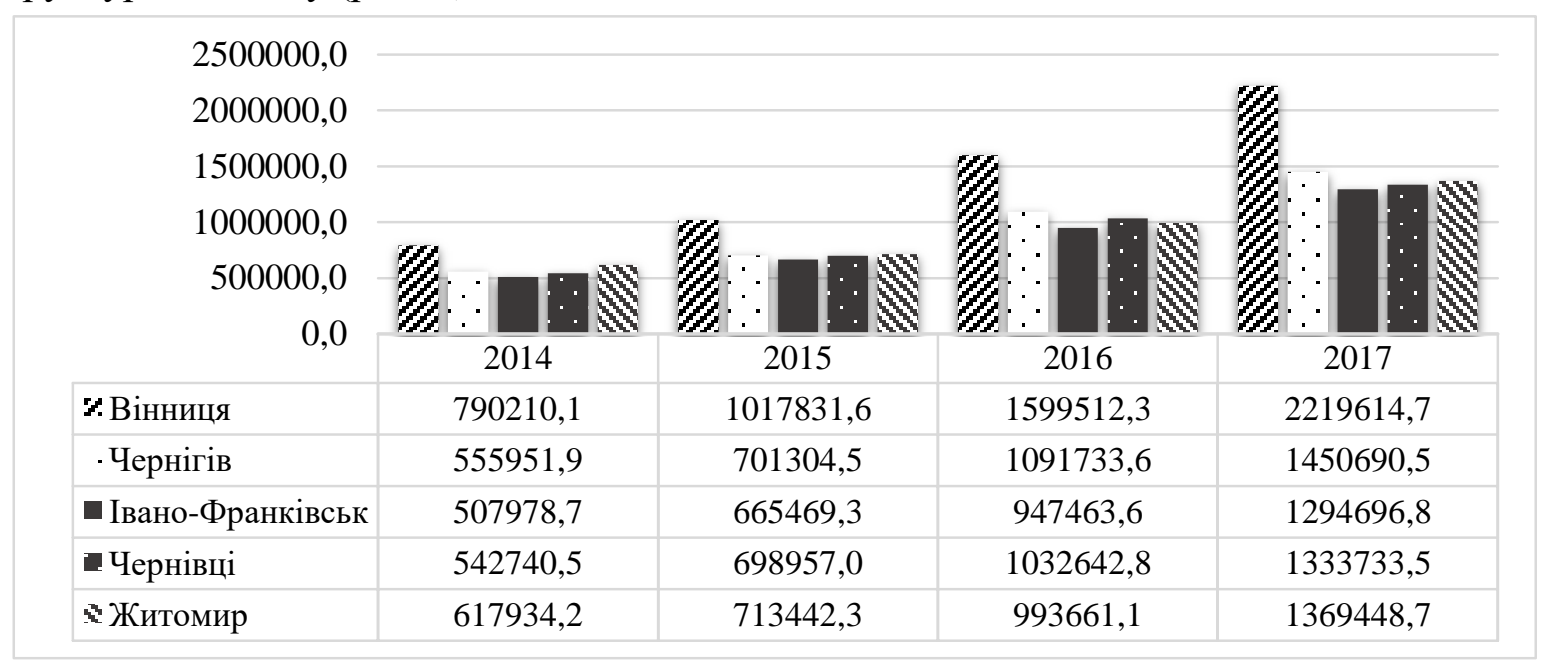

Рисунок 3 - Обсяги власних надходжень місцевих бюджетів, тис. грн.

Бачимо, що починаючи 32014 року у всіх зазначених міст відзначається позитивна динаміка, так у порівнянні з 2014 роком в середньому у 2,5 рази збільшився обсяг доходів (загальний та спеціальний фонд) місцевих бюджетів.

Але для більш детальної картини розглянемо частку власних надходжень в структурі бюджету (Табл. 1)

Таблиця 1- Частка власних надходжень в бюджеті міста у період з 2014-2017 роки

\begin{tabular}{|c|c|c|c|c|c|}
\hline Рік & Вінниця, \% & Чернігів, \% & Івано-Франківськ, \% & Чернівці,\% & Житомир,\% \\
\hline 2014 & 44,1 & 41,2 & 51,9 & 52,9 & 48,4 \\
\hline 2015 & 45,3 & 41,8 & 47,3 & 50,4 & 45,9 \\
\hline 2016 & 53,4 & 47,8 & 50,5 & 54,1 & 48,6 \\
\hline 2017 & 51,2 & 45,7 & 50,8 & 52,9 & 47,9 \\
\hline
\end{tabular}

Джерело: розраховано за даними Державної служби статистики України [6].

Ми бачимо, що частка власних надходжень у період з 2014-2017 роки майже не змінювалась і залишається близько 50\% від усього обсягу доходів бюджетів.

Але, дивлячись на абсолютні значення, то власні надходження місцевих бюджетів за період з 2014-2017 роки постійно збільшувались. Так наприклад у м. Вінниці на 1429404,6 тис. грн., м. Чернігів - 894738,6 тис. грн., м. Івано-Франківськ 786718,1 тис. грн., м. Чернівці - 790993,0 тис. грн. та м. Житомир - 751514,5 тис. грн.

Розглянемо структуру усіх доходів місцевих бюджетів за 2017 рік. (рис.4)

Децентралізація вплинула на структуру доходів місцевих бюджетів, насамперед через збільшення частки податкових надходжень. У структурі податкових надходжень відбулось збільшення таких видів доходів, як: податок

на доходи фізичних осіб та акцизного податку з реалізації суб'єктами господарювання роздрібної торгівлі підакцизних товарів. Так ми бачимо, що близько $25 \%$ в усіх містах займає податок на доходи фізичних осіб, близько 5-6\% податок на майно та 6\% єдиний податок. На нашу думку, саме на ці джерела наповнення бюджету органи місцевого самоврядування мають опосередкований вплив через розвиток малого та середнього підприємництва. 


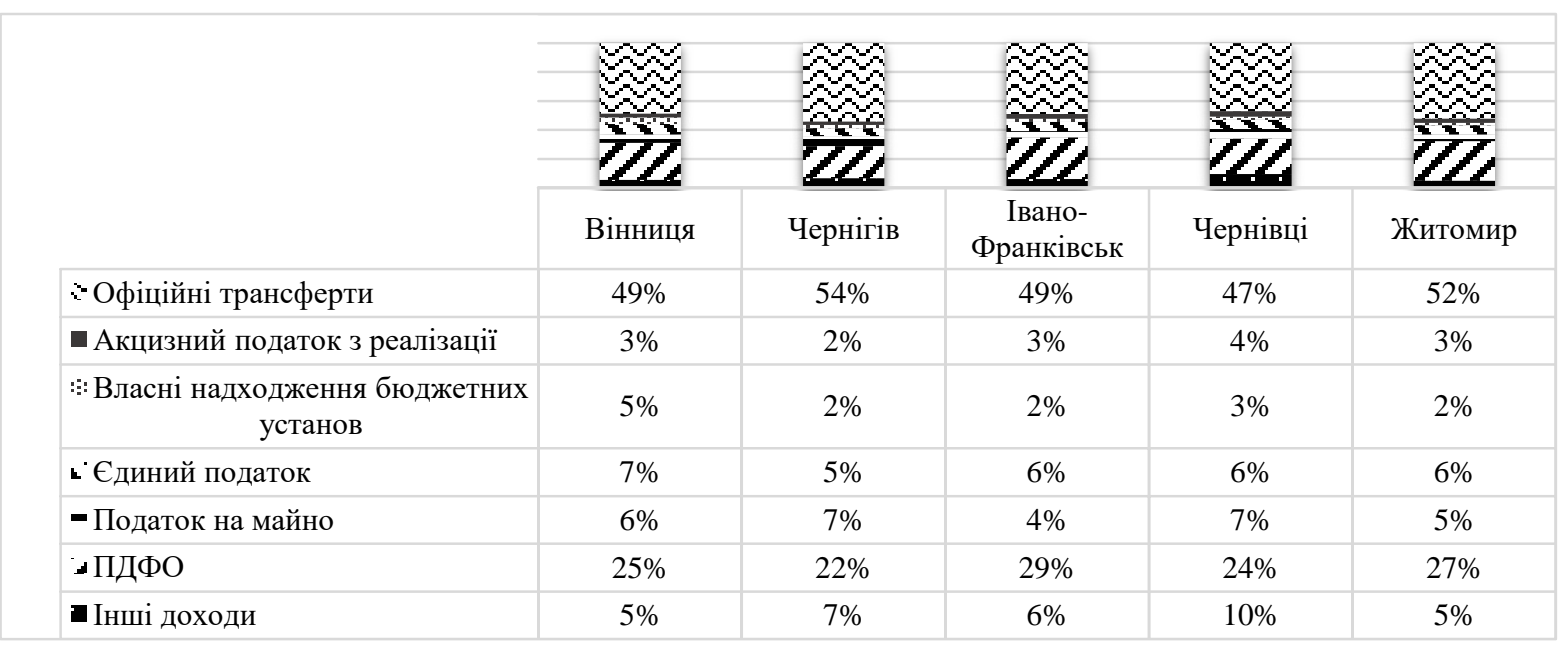

Рисунок. 4 - Структура доходів місцевих бюджетів за 2017 рік, \%

Розглянемо динаміку надходжень від єдиного податку, як основного, який надходить від суб’єктів господарювання в місцевий бюджет (рис. 5).

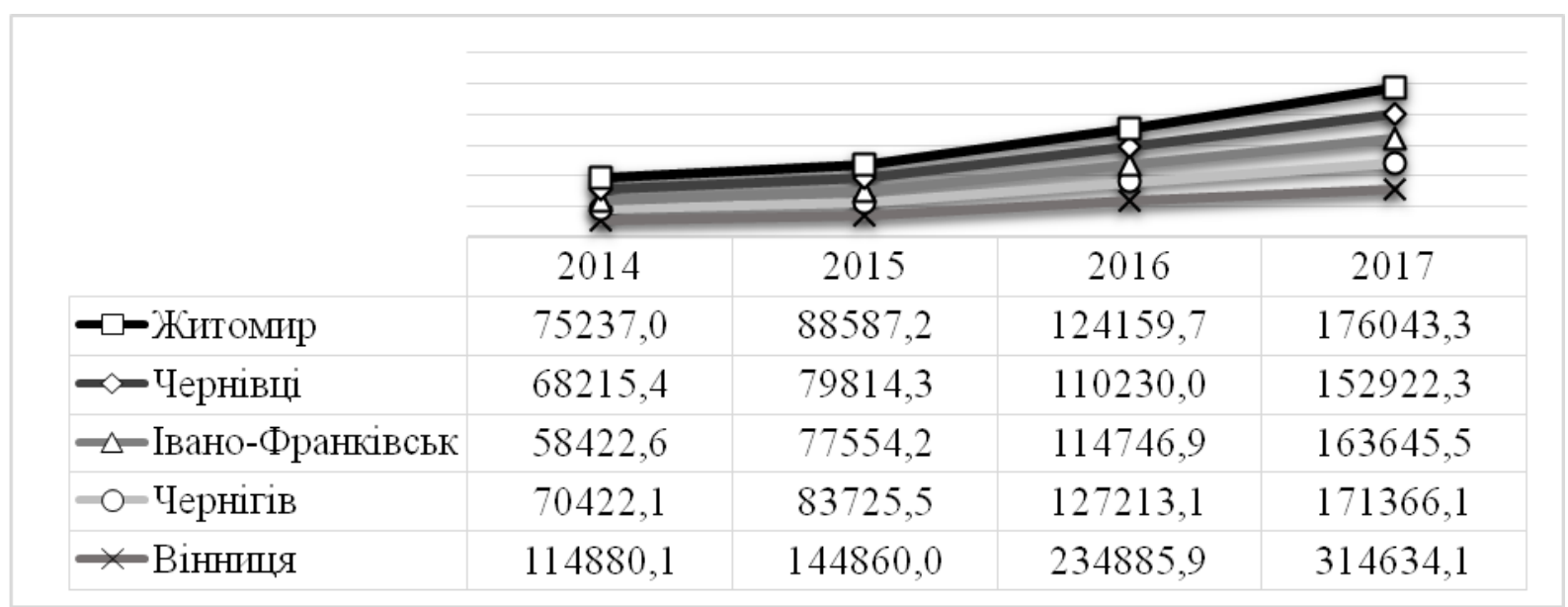

Рисунок 5 - Динаміка надходжень єдиного податку від суб’єктів господарювання за період 2014-2017 рр., тис. грн.

Бачимо, що в усіх розглянутих містах позитивна динаміка надходжень єдиного податку, але, розглянувши динаміку кількості фізичних осіб-підприємців (рис. 6), ми бачимо, що за період 2013-2017 роки надходження єдиного податку збільшувались навіть при зменшенні кількості суб'єктів, це обумовлено внесенням 32015 року законодавчих зміни щодо групування платників за відповідними критеріями та фактична трансформація фіксованого сільськогосподарського податку в єдиний податок IV групи. В цілому високий рівень виконання планових показників зі сплати єдиного податку вказує на наявність внутрішніх резервів для розвитку спрощеної системи оподаткування доходів малого бізнесу в Україні. Застосування відносних ставок єдиного податку для платників I та II груп, відповідно, відсутність зв’язку між фінансовими результатами їх діяльності та розміром сплаченого податку забезпечує місцеві бюджети доходами, ризик недоотримання яких надзвичайно низький. Це дозволяє розглядати єдиний податок як стабільне та прогнозоване джерело податкових надходжень місцевих бюджетів [7]. 


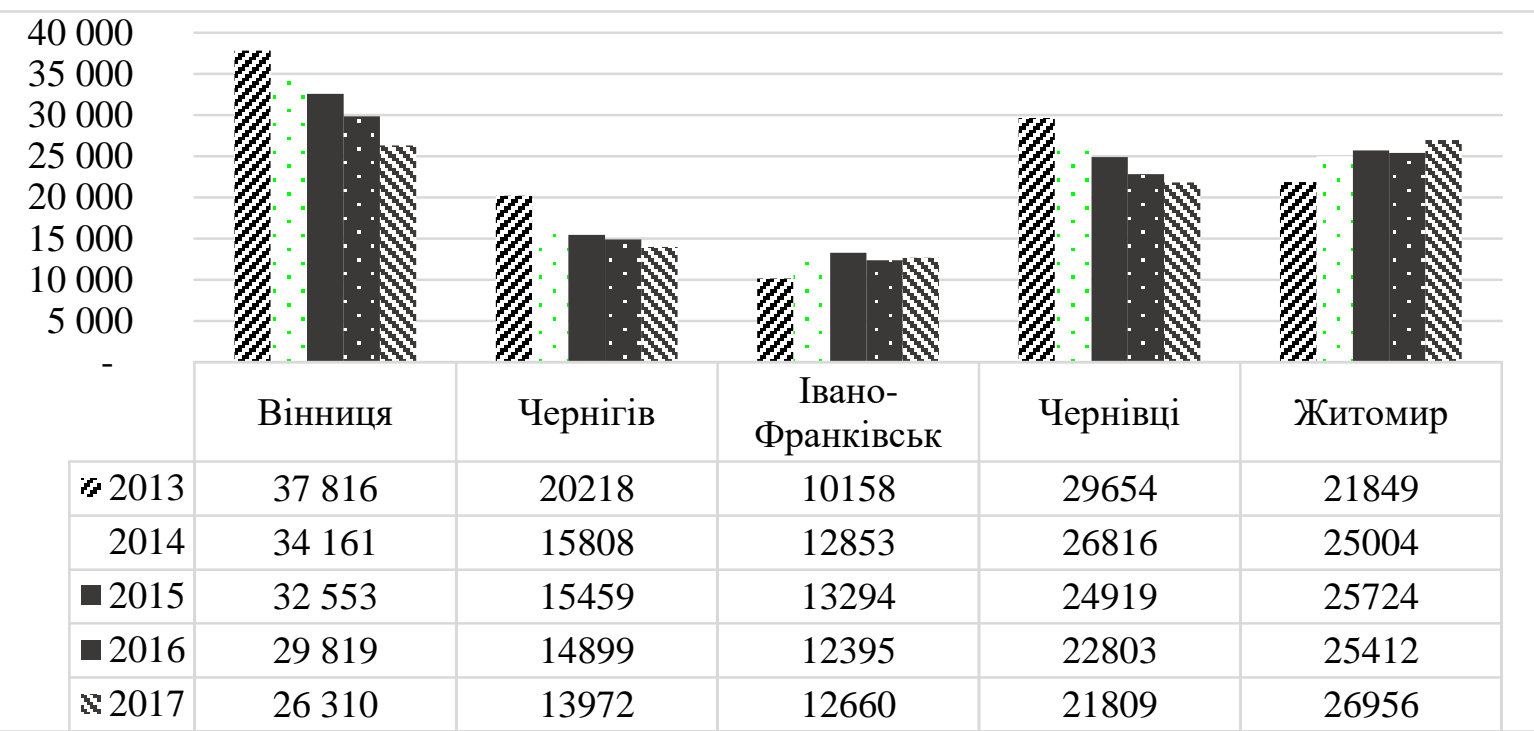

Рисунок 6 - Динаміка кількості фізичних осіб-підприємців за 2013-2017 роки

Саме тому, об'єктивна залежність бюджетного потенціалу органів місцевого самоврядування від рівня підприємницької активності громадян i фінансових результатів підприємств перетворює єдиний податок на інструмент впливу органів влади, яким вони повинні вміло користуватися для

заохочення, підтримки та стимулювання розвитку суб'єктів малого бізнесу на відповідній території.

Розглянемо обсяги фінансування заходів 3 підтримки малого та середнього підприємництва в розглянутих містах (табл. 2)

Таблиця 2 - Обсяги фінансування програмних документів (заходів, проектів) з підтримки малого та середнього підприємництва, тис. грн.

\begin{tabular}{|l|c|c|c|c|c|}
\hline & $2014 \mathrm{p}$. & $2015 \mathrm{p}$. & $2016 \mathrm{p}$. & $2017 \mathrm{p}$. & $2018 \mathrm{p}$. \\
\hline Вінниця & 0,0 & 0,0 & 0,0 & 0,0 & 5734,0 \\
\hline Чернігів & 49,6 & 22,4 & 63,3 & 23,9 & 803,3 \\
\hline Івано-Франківськ & 50,0 & 30,0 & 150,0 & 150,0 & 200,0 \\
\hline Чернівці & 69,1 & 46,4 & 125,7 & 357,0 & 467,8 \\
\hline Житомир & 0 & 0 & 14,4 & 30,0 & 39,7 \\
\hline
\end{tabular}

Джерело: розраховано за даними [6].

Бачимо, що видатки на підтримку малого та середнього підприємництва на протязі розглянутого періоду були досить низькими, в деяких містах, таких як Вінниця та Житомир з коштів місцевого бюджету майже не було видатків на вищезазначені заходи, але на 2918 рік прослідковується позитивна динаміка, так наприклад у м. Вінниці передбачено видатки на заходи 3 підтримки малого та середнього підприємництва у сумі 5734 тис. грн.

Отже, підтримка малого та середнього підприємництва за рахунок коштів місцевих бюджетів $\epsilon$, безперечно, значимою для успішного соціально-економічного розвитку регіону та як наслідок збільшення податкових надходжень до бюджету міста. Крім того, суб'єкти господарювання всіх форм власності в процесі своєї діяльності покликані задовольняти потреби регіону у товарах, роботах, послугах, необхідних для регіонального економічного зростання. 
3 метою розвитку малого та середнього підприємництва на місцевому рівні та як наслідку збільшення доходів місцевого бюджету та підвищення фінансової спроможності регіону, було розроблено концепцію (рис. 7).

Визначені наступні задачі розвитку малого та середнього підприємництва [8]:

- покращення бізнес клімату в регіоні;

- поєднання інтересів суб'єктів підприємницької діяльності (юридичних і фізичних осіб) з інтересами відповідних адміністративно-територіальних одиниць;

- стимулювання підприємницької ініціативи за рахунок власних фінансових, майнових, трудових, інтелектуальних ресурсів регіону;

- забезпечення продуктивної зайнятості населення шляхом створення нових (економічно доцільних) робочих місць, самозайнятості;

- наповненню державного і місцевих бюджетів;

- розвиток спроможностей малого та середнього підприємництва;

- підвищення підприємницької культури населення.

Мета розвитку малого та середнього підприсмництва - збільшення доходів місцевого бюджету та підвищення фінансової спроможності регіону

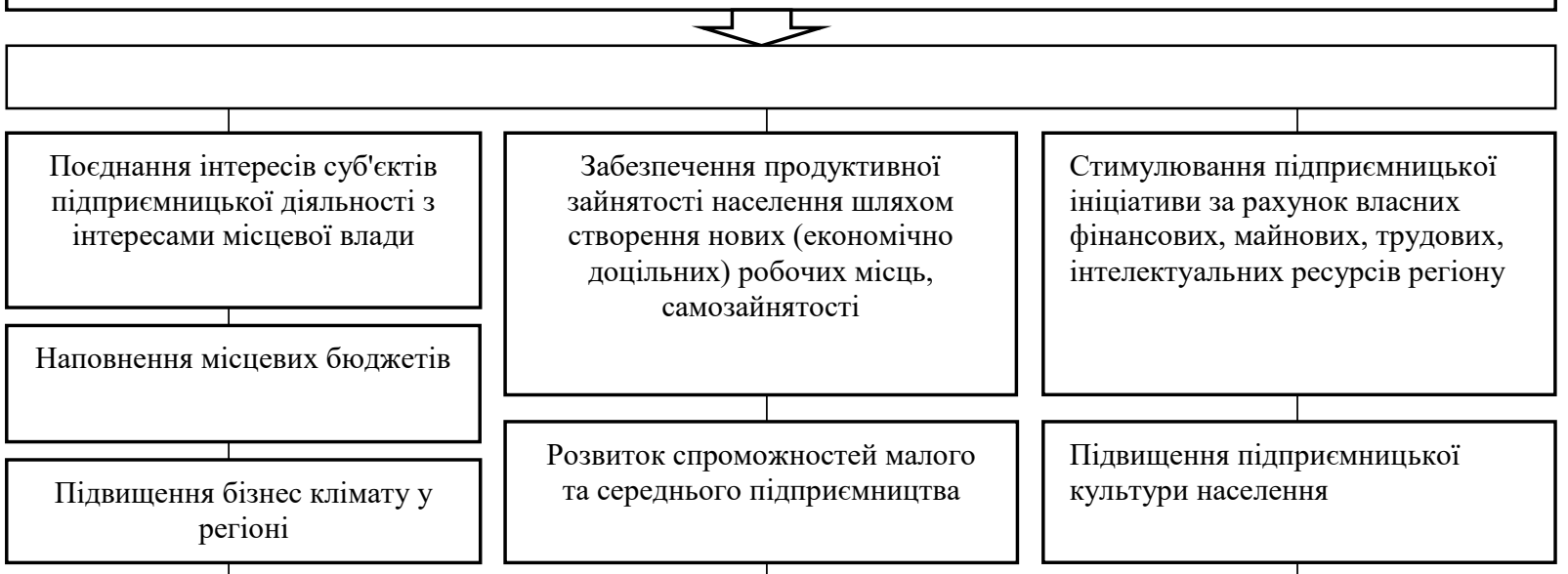

Методи організаційно-економічного механізму розвитку малого та середнього підприємництва

\begin{tabular}{|c|c|c|c|}
\hline & & & \\
\hline Конкурентні & Фінансові & Інституційні & Інформаційно- \\
\hline $\begin{array}{l}\text { - розробка програм } \\
\text { покращення системи } \\
\text { професійно-технічної } \\
\text { освіти; } \\
\text { - розвиток структур з } \\
\text { перепідготовки та } \\
\text { підбору кадрів; } \\
\text { - удосконалення діючих } \\
\text { та створення нових } \\
\text { об'єктів } \\
\text { інфраструктури } \\
\text { підтримки } \\
\text { підприємництва }\end{array}$ & $\begin{array}{l}\text { - компенсація } \\
\text { відсоткових ставок за } \\
\text { кредитами з місцевих } \\
\text { бюджетів; } \\
\text { - надання пільгових } \\
\text { кредитів; } \\
\text { - дотації за субвенції; } \\
\text { - здійснення різних форм } \\
\text { фінансової підтримки } \\
\text { інноваційної діяльності }\end{array}$ & $\begin{array}{l}\text { удосконалення } \\
\text { нормативно правової } \\
\text { бази } з \text { питань розвитку } \\
\text { підприємництва; } \\
\text { оптимізація дозвільних } \\
\text { процедур; } \\
\text { аналіз та оптимізація } \\
\text { місцевих регуляторних } \\
\text { актів }\end{array}$ & $\begin{array}{l}\text { надання інформації } \\
\text { щодо форм і методів } \\
\text { державної підтримки } \\
\text { малого бізнесу; } \\
\text { освітні заходи для } \\
\text { бізнесу; } \\
\text { налагодження дієвої } \\
\text { комунікації міської } \\
\text { влади та МСП }\end{array}$ \\
\hline так & \multicolumn{2}{|c|}{ Мета досягнута } & $\mathrm{Hi}$ \\
\hline
\end{tabular}

Рисунок 7 - Концепція збільшення доходів місцевого бюджету за рахунок розвитку малого та середнього підприємництва 
Для вирішення вищезазначених задач, були визначені наступні методи організаційно-економічного механізму розвитку малого та середнього підприємництва, a саме: конкурентні, фінансові, інституційні та інформаційно-консультаційні. Використання цих методів вимагає значних витрат 3 місцевих бюджетів, але запровадження такої підтримки малого та середнього підприємництва сприятиме не тільки розвитку бізнесу а й регіону в цілому.

Висновки. Отже, реалізація усіх вищезазначених заходів сприятиме процесам виходу малого та середнього підприємництва на європейський рівень розвитку, поліпшенню бізнес-клімату, зміцненню позицій малого підприємництва в загальній структурі вітчизняної економіки, модернізації у сфері малого підприємництва, спрямованої на збільшення його внеску у соціально-економічний розвиток регіонів, підвищенню ефективності малого підприємництва, у тому числі збільшення його складової в обсягах вітчизняного промислового та сільськогосподарського виробництва і як наслідку наповнення дохідної частини місцевих бюджетів.

\section{Література:}

1. Ставерська Т. О., Шевчук І.Л. Реформування міжбюджетних відносин в Україні // ScienceRise. - 2015. - № 6(3). - C. 29-34. [Електронний ресурс] - Режим доступу: http://nbuv.gov.ua/UJRN/texc_2015_6\%283\%29_7

2. Бюджетний кодекс України [Електронний ресурс]. - Режим доступу: http:// www.rada.gov/ua

3. Закон України «Про місцеве самоврядування в Україні» [Електронний pecypc]. - Режим доступу: http: // www.rada.gov.ua.

4. Набатова Ю.О., Ус Т.В. Формування місцевих бюджетів в умовах децентралізації фінансових ресурсів // Ефективна економіка. [Електронний ресурс] Режим доступу: http://www.economy.nayka.com.ua/?op=1\&z=4100

5. Моніторинг процесу децентралізації влади та реформування місцевого самоврядування [Електронний ресурс]. - Режим доступу: http://decentralization.gov.ua/mainmonitoring

6. Державна служба статистики України. URL: http://www.ukrstat.gov.ua

7. Бак Н. А. Місцеве оподаткування в Україні : стан і перспективи посилення дієвості// Економіка: Реалії часу. - №1(29). - Одеса, 2017. - с. 12-26

8. Чорній. Л. І. Регіональні програми розвитку малого і середнього підприємництва: структура, пріоритети, фінансування. - К.: Центр громадської експертизи, Центр міжнародного приватного підприємництва, 2015. - 24 с. 